\title{
MORTALITY AND COMPLICATIONS IN PATIENTS WITH PORTAL HYPERTENSION WHO UNDERWENT TRANSJUGULAR INTRAHEPATIC PORTOSYSTEMIC SHUNT (TIPS) - 12 years experience
}

\author{
Fernanda Ribeiro FUNES ${ }^{1}$, Rita de C. M. A. da SILVA², Paulo César ARROYO Jr. ${ }^{2}$, \\ William José DUCA $^{3}$, Adinaldo Adhemar Menezes da SILVA ${ }^{2}$ and Renato Ferreira da SILVA ${ }^{2}$
}

\begin{abstract}
Context - Transjugular intrahepatic portosystemic shunt (TIPS) is the non-surgical treatment option with low level of morbi-mortality and possibility of accomplishment in patients with severe hepatic dysfunction which aims at decompressing the portal system treating or reducing the portal hypertension complications. Objective - Outline the profile analyze global and early mortality, and the complications presented by cirrhotic patients who underwent TIPS for treatment of digestive hemorrhage by portal hypertension. Method - Retrospective study based on the data bank of cirrhotic patients' medical reports, who underwent TIPS for digestive hemorrhage by portal hypertension treatment who did not respond to clinical endoscopic treatment, and were assisted from 1998 to 2010 in the Liver Transplant Service at a university hospital. The study was approved by the Committee of Ethics and Research. Results - The sample was comprised of $72(84.7 \%)$ patients, being 57 (79.2\%) males, average age 47.7 years (age range from 16 to 85 years and SD = 13), $21(29.2 \%)$ patients presented liver disease as cause excessive intake of alcoholic drinks; $21(29.2 \%)$ contamination by hepatitis virus, $16(22.2 \%)$ excessive alcohol intake associated with virus and $14(19.4 \%)$ patients presented other causes. As for initial classification, 14 (20\%) had Child-Pugh A, 33 (47.1\%) Child-Pugh B and 23 (32.9\%) Child-Pugh C. Initial MELD was obtained in 68 patients being 37 (54.4\%) higher than 15 points while 31 (45.6\%) had up to 15 points. Early death occurred in 19 (26.4\%). Global mortality occurred in 41 (60.3\%). Conclusions - Mortality is directly related to clinical factors of patients, being Child-Pugh and MELD classifications predictors of mortality, with more impact in patients with Child-Pugh class $\mathrm{C}$ and MELD $>15$. The complications found were similar to those described in the literature, although the dysfunction by stent stenosis $(26.4 \%)$ was lower than in the most of the studies and the encephalopathy incidence $(58.3 \%)$ was higher. Probably, the high incidence of encephalopathy is explained by the low incidence of stenosis.
\end{abstract}

HEADINGS - Portasystemic shunt, transjugular intrahepatic. Hypertension, portal.

\section{INTRODUCTION}

Hepatic cirrhosis is a chronic disease histologically characterized by the presence of regenerative nodules surrounded by diffuse fibrosis ${ }^{(21)}$. It is the common final stage of several hepatic disorders of different etiologies, as ethylism and viral chronic hepatitis, besides metabolic, vascular or biliary ${ }^{(13)}$.

The distortion of the hepatic architecture caused by cirrhosis leads to the increase of intrahepatic resistance resulting in portal hypertension ${ }^{(11,21)}$, being this its major complication with important clinical complications such as ascites, digestive hemorrhage by gastroesophageal varices, hypertensive gastropathy, congestive splenomegaly, hepatic encephalopathy, hepatorenal syndrome, hepatopulmonary syndrome, change in the metabolism of drugs or endogenous substances which are usually eliminated by the liver ${ }^{(2)}$.

Cirrhotic patients with portal hypertension present high prevalence of gastroesophageal varices rupture is one of the most severe and frequent complications being possible to occur in up to $40 \%$ of these patients $^{(18)}$. High digestive bleeding is one of the main death causes in cirrhotic patients ${ }^{(29)}$, with mortality around $30 \%$ in the course of acute hemorrhage and

${ }^{1}$ Post graduate Health Sciences, Faculdade de Medicina de São José do Rio Preto (FAMERP); ${ }^{2}$ Unit of Surgery and Liver Transplantation, Hospital de Base FUNFARME FAMERP; ${ }^{3}$ Department of Vascular Surgery and Angiology, Hospital de Base FUNFARME/FAMERP, São José do Rio Preto, SP, Brazil.

Correspondence: Dr. Renato Ferreira da Silva - Avenida Juscelino Kubitschek de Oliveira - Condomínio Recanto Real - Rua 8, casa 140 - $15092-259$ - São José do Rio Preto, SP, Brazil. E-mail: renatosilva@famerp.br 
from $15 \%$ to $20 \%$ with adequate treatment. The risk of rebleeding after the first hemorrhage episode within a year is from $60 \%$ to $80 \%$ associated with high morbimortality ${ }^{(18)}$.

There are several factors associated with the risk of bleeding, and among them the portal pressure gradient $>$ $12 \mathrm{~mm} \mathrm{Hg}$, hepatic dysfunction evaluated by Child-Pugh classification, varices caliber and continuous use of alcoholic drinks $^{(9,12)}$. Pressure of ascites, serous albumin $<3.3 \mathrm{~g} / \mathrm{dL}$ and portal pressure gradient $>18 \mathrm{~mm} \mathrm{Hg}$ are important risk factors associated with rebleeding ${ }^{(18)}$.

There are many therapeutic options for the treatment of acute and recurrent varices bleeding, which include pharmacological, endoscopic treatment and the surgical portosystemic shunts ${ }^{(9,11,12,23)}$.

The transjugular intrahepatic portosystemic shunt (TIPS) appeared as a non-surgical option as treatment for portal hypertension complications due to the low level of morbimortality, possibility of performance in patients with severe hepatic dysfunction, and for being a minimally invasive procedure that can be carried out without the need of general anesthetics.

TIPS aim is to decompress the portal system, treating or reducing the complications of the portal hypertension. The procedure is carried out by intervening radiologic technique, with percutaneous puncture of the internal jugular vein and, creation of an intrahepatic communication between a branch of the portal vein and the hepatic vein with the insertion of an expandable metallic stent in the parenchymatous path ${ }^{(9)}$, and its success rate is approximately $90 \%{ }^{(3)}$.

Despite TIPS success in decompressing portal vein, the hepatic function may worsen after the procedure, early mortality reported is from $3 \%$ to $44 \%(5,20)$ and the mortality rate in one year is from $10 \%$ to $58 \%{ }^{(5)}$. Recent studies show that factors associated with bad prognosis in patients who underwent TIPS include previous encephalopathy, ChildPugh class C, emergency TIPS and MELD $>18$, being these mortality predictors ${ }^{(5,10,20,24,28)}$.

TIPS complications divide in those concerning its installation and immediate and late hemodynamic consequences which occur in about $10 \%$ of patients being mostly mild ${ }^{(6,23)}$. More severe complications occur from $1 \%$ to $2 \%$ and include hemoperitoneum, sepsis, hemobilia, worsening of hepatic and cardiopulmonary insufficiency ${ }^{(23)}$. After the procedure, there may occur complications as lung acute edema, pneumonias, adult respiratory distress syndrome and kidney acute insufficiency ${ }^{(4)}$. Bacteremia or bacterial sepsis may also occur from $1 \%$ to $2 \%$ of cases, being necessary, before the procedure, perform antibiotic prophylaxis ${ }^{(22)}$.

Among long term complications, the most common are hepatic encephalopathy which occurs in up to $30 \% \%^{(29)}$ and stent dysfunction by stenosis $(18 \%$ to $78 \%$ ) or thrombosis $(10 \% \text { to } 15 \%)^{(3)}$. A metanalysis ${ }^{(29)}$ showed that the most common cause of rebleeding in patients with TIPS is stent dysfunction and, that the rebleeding rate is progressive reaching up to $26 \%$ in 1 year and $32 \%$ in 2 years.

This study aimed at describing the profile, analyzing global and early mortality as well as the complications in cirrhotic patients who underwent TIPS as treatment for digestive hemorrhage by portal hypertension.

\section{METHODS}

Retrospective descriptive study of data collected by means of revision of patients' medical reports, who were referred to TIPS installation from 1998 to 2010 in the Liver Transplant Unit of Hospital de Base and São José do Rio Preto Medical School-FAMERP, São José do Rio Preto, SP, Brazil. The study was approved by the Committee of Ethics and Research of the Medical School of São José do Rio Preto - FAMERP, under approval \#114/2010.

The statistical analysis: univariate analyses of quantitative and qualitative variables were performed by descriptive analysis, including sector graph. To evaluate the association between qualitative variables was applied the independent chi-square test. Results were considered statistically significant when $P<0.05$. The statistical calculations were obtained by the Minitab ${ }^{\circledR} 15$ software.

\section{RESULTS}

All the patients with portal hypertension who underwent TIPS because of failure in digestive hemorrhage treatment were evaluated. Those who had TIPS installed successfully were included, comprising a total of 72 patients. Figure 1 shows how the casuistic of this study was obtained.

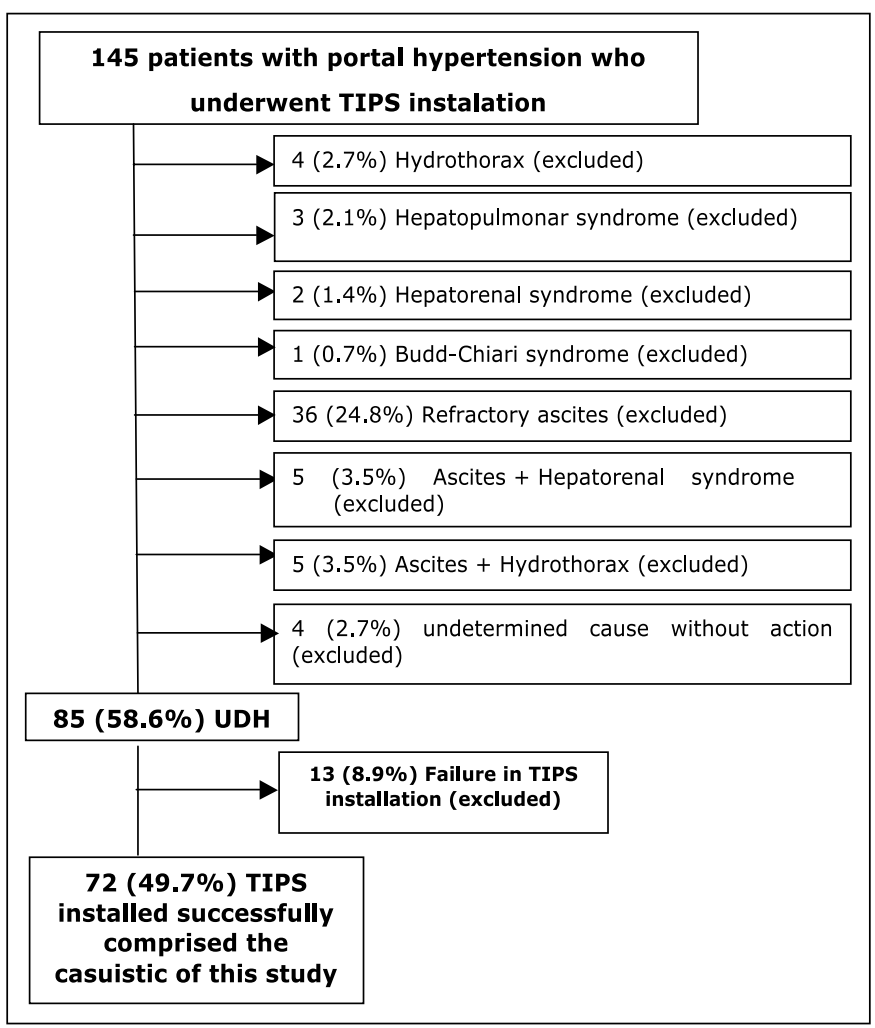

FIGURE 1. Chart showing how the casuistic of this study was obtained 
Exclusion criteria were: patients who had TIPS installed for other etiologies such as non-treatable ascites, HRS, hepatic hydrothorax. The demographic and clinical characteristics of patients included in this study are shown in Table 1 .

TABLE 1. Demographic characteristics of 72 patients who underwent TIPS included in this study

\begin{tabular}{lcc}
\hline Characteristics & $\begin{array}{c}72 \text { patients with } \\
\text { TIPS installed }\end{array}$ & $\begin{array}{c}\text { 13 patients with } \\
\text { failure in TIPS** }\end{array}$ \\
\hline $\begin{array}{l}\text { Age (y) md (year) } \\
\text { Gender }\end{array}$ & $47.4(18-85)$ & $48.0(28-70)$ \\
M & $57(79.2 \%)$ & $9(69.2 \%)$ \\
F & $15(20.8 \%)$ & $4(30.8 \%)$ \\
Cirrhosis causes & & \\
$\quad$ Virus B $\backslash C$ & $21(29.2 \%)$ & $4(30.8 \%)$ \\
Alcohol & $21(29.2 \%)$ & $4(30.8 \%)$ \\
Virus + alcohol & $16(22.2 \%)$ & $1(7.6 \%)$ \\
Others* & $14(19.4 \%)$ & $4(30.8 \%)$ \\
\hline
\end{tabular}

* criptogenic cirrhosis, NASH, primary and secondary biliar cirrhosis, auto-immune hepatitis ** non-successful case in years ( 1 in 1998, 4 in 1999, 3 in 2000, 1 in 2003, 2 in 2004, 1 in 2005 e 1 in 2007)

Statistical results concerning TIPS indication, TIPS characterization (urgency or elective procedure); number of stents implanted, initial rating by Child-Pugh classification and MELD are presented in Table 2. Upper digestive

TABLE 2. Results of clinical variables analysed in 72 patients with portal hipertension who underwent TIPS by digestive hemorrhage

\begin{tabular}{lc}
\hline Variable & General result \\
\hline TIPS indication & $62(86.1 \%)$ \\
Upper digestive hemorrhage (UDH) & $01(1.4 \%)$ \\
Low digestive hemorrhage (LDH) & $09(12.5 \%)$ \\
UDH associated to refractory ascite or to & \\
hepatorenal syndrome & \\
\hline TIPS characterization & $37(51.4 \%)$ \\
Urgency & $35(48.6 \%)$ \\
Elective & $63(87.5 \%)$ \\
\hline Number of stents & $07(9.7 \%)$ \\
One & $01(1.4 \%)$ \\
Two & $01(1.4 \%)$ \\
Three & $14(20.0 \%)$ \\
Four & $33(47.1 \%)$ \\
\hline Child-Pugh classification** & $23(32.9 \%)$ \\
A (5 to 6 points) & $31(45.6 \%)$ \\
B (7 to 9 points) & $37(54.4 \%)$ \\
C (10 to 15 points) & \\
\hline MELD classification*** & \\
Up to 15 points & \\
Above 15 points & \\
\hline 8 pis with & \\
\hline
\end{tabular}

*8 patients with ascites and 1 patient with ascites associated to hepatorenal syndrome; $* * 2$ patients not evaluated; $* * * 4$ patients not evaluated hemorrhage is the most prevalent, occurring in $62(86.1 \%)$ patients, also appearing associated with other complications in $9(12.5 \%)$ patients. However, low digestive hemorrhage motivated TIPS in only $1(1.4 \%)$ patient.

The procedure was carried out in an elective way in 35 $(48.6 \%)$ patients and in urgency mode in $37(51.4 \%)$. The great majority of patients $63(87.5 \%)$ had only one stent installed and $7(9.7 \%)$ received two stents, and only 1 patient needed to have three or four stents installed (1.4\%).

Child-Pugh and MELD indices were calculated before TIPS performance. Concerning initial rating by Child-Pugh classification, it was observed that $14(20 \%)$ patients were Child-Pugh A, most of the patients 33 (47.1\%) were ChildPugh B, while $23(32.9 \%)$ Child-Pugh C. Initial MELD was obtained in 68 patients of the sample being the median 14.5 with minimum value 6 and maximum 37 . The results also show that $37(54.4 \%)$ of patients reached more than 15 points, whereas $31(45.6 \%)$ had up to 15 points. The average hospitalization time of patients who underwent the procedure was 10.8 days (interval from 1-82 days). From the 72 patients studied who underwent TIPS, $21(29.2 \%)$ also underwent liver transplant.

Patients' mortality was evaluated according to global death and death occurring in up to 30 days (early mortality). From the 72 patients studied, 19 (26.4\%) died precociously. In this analysis, 68 patients were considered global mortality, since life status was not confirmed in 4 patients for losing track of them. From this total, $41(60.3 \%)$ died, being this the global mortality rate which is represented in Figure 2.

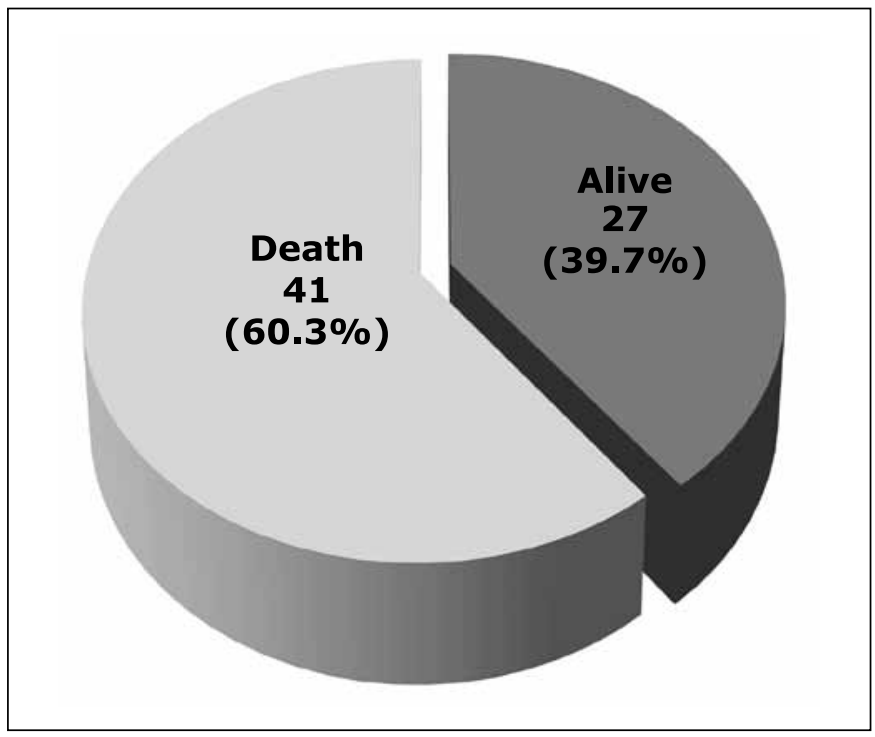

FIGURE 2. Percentage distribution of patients according to global mortality

The association of mortality with etiology, TIPS characterization, initial rating Child-Pugh and MELD classifications were analyzed by chi-square test. The results present 
TABLE 3. Frequency and percentage distribution of global mortality according to etiology, TIPS characterization, Child-Pugh and MELD Classification. $P$ value referent to independent chi-square test

\begin{tabular}{|c|c|c|c|c|c|}
\hline \multirow{2}{*}{ Associated variable } & & \multicolumn{2}{|c|}{ Patient's status } & \multirow[b]{2}{*}{ Death } & \multirow{2}{*}{$P$ value } \\
\hline & & Total & Alive & & \\
\hline \multirow{4}{*}{ Etiology } & Alcohol & 19 & $06(31.6 \%)$ & $13(68.4 \%)$ & 0.797 \\
\hline & Virus & 20 & $09(45.0 \%)$ & $11(55.0 \%)$ & \\
\hline & Alcohol/Virus & 16 & $06(37.5 \%)$ & $10(62.5 \%)$ & \\
\hline & Other & 13 & $06(46.1 \%)$ & $07(53.9 \%)$ & \\
\hline \multirow{2}{*}{ TIPS characterization } & Urgency & 36 & $14(38.9 \%)$ & $22(61.1 \%)$ & 0.884 \\
\hline & Elective & 32 & $13(40.6 \%)$ & $19(59.4 \%)$ & \\
\hline \multirow{3}{*}{ Child-Pugh classification } & A & 14 & $07(50.0 \%)$ & $07(50.0 \%)$ & 0.002 \\
\hline & $\mathrm{B}$ & 30 & $17(56.7 \%)$ & $13(43.3 \%)$ & \\
\hline & C & 22 & $02(9.1 \%)$ & $20(90.9 \%)$ & \\
\hline \multirow{2}{*}{ MELD classification } & Up to 15 & 35 & $17(48.6 \%)$ & $18(51.4 \%)$ & 0.044 \\
\hline & Above 15 & 29 & $07(24.1 \%)$ & $22(75.9 \%)$ & \\
\hline
\end{tabular}

TABLE 4. Frequency and percentage distribution of early death according to etiology, TIPS characterization, Child-Pugh and MELD classification. $P$ value referent to independent chi-square test

\begin{tabular}{|c|c|c|c|c|c|}
\hline \multirow{2}{*}{ Associated variable } & \multirow{2}{*}{ Status } & \multicolumn{2}{|c|}{$P$ value } & \multirow[b]{2}{*}{ Death in 30 days } & \multirow{2}{*}{$P$ value } \\
\hline & & Total & Alive & & \\
\hline \multirow{4}{*}{ Etiology } & Alcohol & 21 & $15(71.4 \%)$ & $06(28.6 \%)$ & 0.982 \\
\hline & Virus & 21 & $16(76.2 \%)$ & $05(23.8 \%)$ & \\
\hline & Alcohol/Virus & 16 & $12(75.0 \%)$ & $04(25.0 \%)$ & \\
\hline & Other & 14 & $10(71.4 \%)$ & $04(28.6 \%)$ & \\
\hline \multirow{2}{*}{ TIPS characterization } & Urgency & 37 & $23(62.2 \%)$ & $14(37.8 \%)$ & 0.023 \\
\hline & Elective & 35 & $30(85.7 \%)$ & $05(14.3 \%)$ & \\
\hline \multirow{3}{*}{ Child-Pugh classification } & A & 14 & $12(85.7 \%)$ & $02(14.3 \%)$ & 0.004 \\
\hline & B & 33 & $28(84.9 \%)$ & $05(15.1 \%)$ & \\
\hline & $\mathrm{C}$ & 23 & $11(47.8 \%)$ & $12(52.2 \%)$ & \\
\hline \multirow{2}{*}{ MELD classification } & $\mathrm{Up}$ to 15 & 37 & $31(83.8 \%)$ & $06(16.2 \%)$ & 0.002 \\
\hline & Above 15 & 31 & $18(58.1 \%)$ & $13(41.9 \%)$ & \\
\hline
\end{tabular}

in Table 3 show that mortality is significantly higher among patients with Child-Pugh $\mathrm{C}(90.9 \%)(P=0.02)$ in relation to Child-Pugh A and B. Regarding MELD classification, mortality was higher in patients with initial score above $15(75.9 \%)$ $(P=0.440)$. For etiology and TIPS characterization variables, it was observed that total death percentages keep similar in the different categories in each of these variables and values of $P=0.797$ and $P=0.884$ do not show association with global mortality. On the other hand, early death was associated with Child-Pugh score $(P=0.004)$ and MELD with rating higher then $15(P=0.002)$, Table 4.

For TIPS indication it is noticeable that deaths in up to 30 days occur more frequently for urgency TIPS $(37.8 \%)$ $(P=0.023)$.

Complications reported in the study are presented in Table 5. It is observed that the most prevalent complications were hepatic encephalopathy which occurred in 42 cases $(58.3 \%)$, variceal rebleeding in $23(31.9 \%)$ and TIPS stenosis/dysfunction in $19(26.4 \%)$, being that 9 out of these presented rebleeding. Acute infections (pneumonias, urinary tract infection and spontaneous bacterial peritonitis) in $15(21.1 \%)$ patients and acute kidney insufficiency in $11(15.2 \%)$. Technical complications were observed in $7(9.7 \%)$ patients being 2 cases of cervical hematoma, 1 case of stent fracture with migration to the pulmonary artery, 1 case of stent migration to the right ventricle, 1 case of stent migration to the right atrium, 1 case of pneumothorax associated with cervical hematoma and 1 case of hemothorax.
TABLE 5. Results about complications stemming from TIPS

\begin{tabular}{lcc}
\hline Complication & $\begin{array}{c}\text { Number of } \\
\text { cases }\end{array}$ & $\%$ \\
\hline Hepatic encephalopathy & 42 & $58.3 \%$ \\
Chronic encephalopathy & 12 & $16.7 \%$ \\
Variceal rebleeding & 23 & $31.9 \%$ \\
Early & 11 & $15.2 \%$ \\
Late & 12 & $16.7 \%$ \\
TIPS dysfunction (by stenosis or stent bad & 19 & $26.4 \%$ \\
placement) & 15 & $20.8 \%$ \\
Acute infections* & 14 & $19.4 \%$ \\
Pneumonia & 04 & $5.5 \%$ \\
Spontaneous bacterian peritonitis & 03 & $4.2 \%$ \\
Urinary tract infection & 11 & $15.2 \%$ \\
Acute renal insuficiency & 07 & $9.7 \%$ \\
Technical complications & 05 & $6.9 \%$ \\
Sepsis & 05 & $6.9 \%$ \\
Hipovolimic shock & 04 & $5.5 \%$ \\
Lung acute edema & 03 & $4.2 \%$ \\
Acute respiratory insufficiency & 03 & $4.2 \%$ \\
Acute hepatic Insufficiency & 02 & $2.8 \%$ \\
Rebleeding by other causes** & 02 & $2.8 \%$ \\
Carciologic complications & 01 & $1.4 \%$ \\
Hemorrhagic cerebral vascular accident & 01 & $1.4 \%$ \\
Ischemic colitis & & \\
\hline
\end{tabular}

*occurrence of more than one complication by patient

$* *$ erosive gastritis and gastric ulcer 


\section{DISCUSSION}

TIPS is a well established procedure for patients with portal hypertension complications such as acute bleeding and rebleeding of gastroesophagic varices refractory to clinic endoscopic treatment $t^{(1)}$. TIPS has been used mainly for variceal bleeding, but seems to be efficient in refractory ascites as well( ${ }^{(7)}$.

Owen et al. ${ }^{(22)}$ study demonstrate that esophagogastric varices rebleeding is one of the main causes of death and occurs in $35 \%$ of patients in 6 weeks, and in $75 \%$ of patients in a period of 1 year if secondary therapies are not implemented, being that TIPS may control bleeding in $90 \%$ of acute pictures. The authors found rebleeding with TIPS in up to $25 \%$ of patients and with endoscopic treatment in up to $50 \%$. On the other hand, the index for hepatic encephalopathy is higher in TIPS when compared to endoscopic treatment $30 \%$ and $15 \%$, respectively.

Montgomery et al. ${ }^{(20)}$ evaluating 119 patients who underwent elective TIPS presents early mortality in $13(10.9 \%)$ and Ferral et al. ${ }^{(10)}$ in $19(11.4 \%)$, from the 166 patients studied. Zhuang et al. ${ }^{(30)}$ studies report early mortality of $23(22.3 \%)$ from 103 patients. In a $21 / 2$ year follow-up, Jabbour et al. ${ }^{(14)}$ report global mortality in $21(24.7 \%)$ from the 85 patients studied in the sample, being that 25 of these underwent urgency TIPS with mortality of $13(52 \%)$ patients. Russo et al. ${ }^{(24)}$ in a 3-year follow up show a global mortality of $30(33 \%)$ and early mortality of $18(20.4 \%)$ from 88 patients evaluated, and in a sample of 129 patients followed during a $2 \frac{1}{2}$ year period; Chalasani et al ${ }^{(5)}$ point global mortality of $54(41.9 \%)$ and early mortality of $30(23.2 \%)$.

Yoon et al. ${ }^{(28)}$, in a 73 patient sample who underwent emergency TIPS for acute bleeding control with a 10 -year follow-up report early death in $23(31.5 \%)$ and a global mortality of 43 $(58.9 \%)$ patients. Studies of Tzeng et al. ${ }^{(27)}$, with 107 patients followed by a 10 -year period, report that there were not deaths during TIPS procedure, but $82(77 \%)$ from the patients died during the observation period. Thirty $(28 \%)$ patients had early death and $53(50 \%)$ died within 1 year.

Most of the reports found in the literature show a follow-up shorter than this study's which was during a 12-year period, being observed only two long term studies of 10-year followup $^{(27,28)}$. This study shows early death occurrence in $19(26.4 \%)$ patients and global mortality of $41(60.3 \%)$ patients. Thus, global mortality rate is similar to or inferior when compared to long term studies as Yoon et al. ${ }^{(28)}(58.9 \%)$ and Tzeng et al. ${ }^{(27)}$ $(77 \%)$. Yet, early mortality which independs on the follow-up period presents similar rating to those shown in literature as in Zhuang et al. ${ }^{(30)}(22.3 \%)$, Chalasani et al. ${ }^{(5)}(23.2 \%)$, Tzeng et al. ${ }^{(27)}(28 \%)$.

In Kisilevzky's ${ }^{(17)}$ study with 44 patients, no statistically significant difference in global mortality of patients who underwent TIPS was found when compared to those performed in elective indication or urgency, whose results corroborate those found in this study.

Encarnación et al. ${ }^{(8)}$ study with 65 patients report that patients who undergo urgency TIPS have a significantly worse prognosis than those which are performed in elective way. Early mortality in urgency TIPS was $28 \%$ and $4 \%$ in elective TIPS $(P=0.043)$. Yet, Kisilevzky ${ }^{(17)}$ did not demonstrate statistically significant difference showing early mortality of $21.4 \%$ of patients undergoing urgency TIPS and $10 \%$ in elective TIPS $(P=$ $0.313)$. In this study, when evaluating early mortality, it is found statistically significant difference $(P=0.023)$ being higher the number of deaths in urgency procedures in $14(37.8 \%)$ patients when compared to elective procedure in $5(14.3 \%)$ patients corroborating Encarnación et al. study( ${ }^{(8)}$.

Ferral et al. study ${ }^{(10)}$ with 166 patients report statistically significant difference in early mortality rate in patients with MELD $\leq 17(7.3 \%)$ which is lower when compared to patients with MELD > $17(7.3 \%)(P=0.01)$. In patients with MELD $\leq 10$ early mortality was $0 \%$ and in patients with MELD $\geq 25$ it was $42.6 \%$. This study shows early mortality in patients with MELD $>15$ of $41.9 \%(P=0.002)$ and global mortality of $75.9 \%(P=0.044)$ when compared to patients with MELD $\leq 15$ with early mortality of $16.2 \%$ and global mortality of $51.4 \%$.

Encarnación et al. ${ }^{(8)}$, in a study with 65 patients reported early mortality in $38(8.8 \%)$ patients, Child-Pugh class A and B and in $9(29 \%)$ patients class $C$ with statistically significant difference. Russo et al. ${ }^{(24)}$ evaluating 90 patients report global mortality in patients with Child-Pugh class A of $12 \%$, class B of $28 \%$ and class $\mathrm{C}$ of $54 \%$, showing statistically significant difference $(P=0.01)$. Corroborating literature, this study presents statistically significant difference in early mortality which is higher in patients Child-Pugh class $\mathrm{C}(52.2 \%)$ when compared to classes A $(14.3 \%)$ and $\mathrm{B}(15.1 \%)(P=0.004)$ and in global mortality also higher in class $\mathrm{C}(90.9 \%)$ when compared to classes A $(50 \%)$ and B $(43.3 \%)(P=0.002)$. Data from this study corroborate data presented in the literature which show both classifications as predictors of mortality, global as well as early.

TIPS complications may be inherent to the procedure and include questions related to venous access, such as hematoma, infection, lesion of carotid artery and pneumothorax. Other complications include infection, contrast induced nephropathy and cerebral vascular accident (related to the presence of nonrecognizable patent foramen ovale).

Late complications include stent dysfunction, hepatic encephalopathy and esophagogastric variceal rebleeding ${ }^{(15)}$.

Sanyal et al. ${ }^{(25)}$ study report that technical complications which may occur during the procedure are accidental carotid artery injury and tracheal punction, arrhythmias, capsule lesion in up to $33 \%$, although hemoperineous development is rare. Portal vein extrahepatic punction with uncontrollable hemorrhage is seen as a rare complication, fatal though. The main complication related to TIPS is encephalopathy which appears in approximately $30 \%$ of patients and generally occurs between the 2 nd and 3 rd weeks. Another complication related to TIPS is the stenosis which occurs in approximately $75 \%$ of patients from 6 to 12 months.

Boyer and Haskal ${ }^{(3)}$ in a guideline published in 2010, report as the procedure complications, TIPS dysfunction by thrombosis from $10 \%$ to $15 \%$ and by stenosis from $18 \%$ to $78 \%$, and also the worsening or new cases of encephalopathy from $10 \%$ to $44 \%$, chronic encephalopathy from $5 \%$ to $20 \%$, intraperitoneal bleeding from $1 \%$ to $2 \%$ and sepsis from $2 \%$ to $10 \%$.

In a review, Rosado and Kamath ${ }^{(23)}$ report that the worsening and new cases of encephalopathy occur from $13 \%$ to $44 \%$, need of intervention to keep stent patency was reported from 
$18 \%$ to $78 \%$ of patients treated with TIPS. Stent dysfunction is the most common cause of rebleeding which is reported in $26 \%$ within 1 year after procedure and in $32 \%$ in 2 years.

Jabbour et al. ${ }^{(14)}$, analyzing 85 patients who underwent TIPS, report that $35(47.3 \%)$ developed encephalopathy, and $17(20 \%)$ cases of rebleeding, finding stent dysfunction in $7(41 \%)$ of these patients. During average follow-up of 6 months, $45(52 \%)$ patients presented stent dysfunction. Technical complications were observed in $6(7 \%)$ cases, among them a case of migration to the right atrium. Russo et al. ${ }^{(24)}$ in a study with 90 patients points as mains complication stent dysfunction in $44(49 \%)$ cases in a 1-year procedure.

Chalasani et al. ${ }^{(5)}$ in studies with 129 patients report stent dysfunction in $33(26 \%)$ and encephalopathy in $26(20 \%)$. Rebleeding occurred in $10(8 \%)$ of these patients. Fifty-four patients $(41.9 \%)$ died during follow-up period, being that 30 $(23.3 \%)$ died in the first 30 days after TIPS placement. The most common cause of death with more than 30 days was acute hepatic insufficiency.

Zhuang et al. ${ }^{(30)}$ in a sample of 103 patients, report that rebleeding occurred in $30(32.26 \%)$ patients, shunt acute thrombosis in $13(13.6 \%)$ and stenosis in $41(43.16 \%)$. Technical complications were reported in $5(4.8 \%)$ patients including a case of stent migration to the right atrium. Yoon et al. ${ }^{(28)}$ study with 73 patients observed $33(45 \%)$ cases of stent dysfunction and rebleeding occurrence in 1 year in $19(26 \%)$ of patients.

In his study with 44 patients Kisilevzky ${ }^{(17)}$ report complications in $9(20.5 \%)$ patients who underwent TIPS, being encephalopathy in $6(13.7 \%)$ patients, $1(2.27 \%)$ case of inguinal hematoma, $1(2.27 \%)$ case of cervical hematoma and $1(2.27 \%)$ case of hemobilia by lesion of hepatic artery right branch and TIPS occlusion in $5(11.33 \%)$ patients.

As previously demonstrated ${ }^{(26)}$, this study pointed encephalopathy as the main complication in $42(58.3 \%)$ cases, higher indices than those reported in the literature which range from $10 \%$ to $44 \%{ }^{(16)}$. Chronic encephalopathy was observed in 12 $(16.7 \%)$ corroborating with literature with ratings from $5 \%$ to
$20 \%{ }^{(16)}$. Variceal rebleeding was observed in $23(31.9 \%)$ cases matching the reports of Zhuang et al. ${ }^{(30)}(32.26 \%)$ and Rosado and Kamath ${ }^{(23)}(32 \%)$. TIPS dysfunction/stenosis was observed in $19(26.4 \%)$ of cases, lower indices than those found in most of the studies as Jabbour et al. ${ }^{(14)}(52 \%)$, Zhuang et al. ${ }^{(30)}(43.16 \%)$, Russo et al. ${ }^{(24)}(49 \%)$, Yoon et al. ${ }^{(28)}(45 \%)$ and Sanyal et al. ${ }^{\left({ }^{(25)}\right.}$ $(75 \%)$. Acute infections were found in $15(20.8 \%)$, acute kidney insufficiency in $11(15.2 \%)$ and cardiologic complications with arrhythmia in $2(2.9 \%)$ of cases, however these complications are not reported in indices in literature ${ }^{(4)}$. Technical complications were observed in $7(9.7 \%)$ patients, being these similar to those observed in other studies, such as hematomas on the puncture site and stent migration, but with higher indices than those reported by Jabbour et al..$^{(14)}(7 \%)$ and Zhuang et al. ${ }^{(30)}(4.8 \%)$.

Most authors claim that TIPS is an effective procedure in controlling portal hypertension complications, mainly variceal bleeding and ascites. Some authors ${ }^{(14,17,19)}$ also report the use of such procedure as an alternative method for the control of these complications and increase of survival time of patients who wait for transplant as definite alternative, being seen as a "bridge" for liver transplant.

Data found in this study lead us to the conclusion that the hepatic disorder etiology did not influenced early or global mortality in patients. There has been no difference in global mortality rate of patients who underwent urgency TIPS compared to elective, however, the difference between these groups was observed when evaluating early mortality rate, being the number of deaths higher in urgency TIPS. Child-Pugh and MELD classifications proved to be predictors of mortality, being observed higher global and early mortality in patients with Child-Pugh class C and MELD > 15 classification. As for complications found, they were similar to those described in literature, although the percentage of stent stenosis/dysfunction occurrence was lower than in most of the studies and encephalopathy was higher. There was no explanation for the low incidence of stenosis of the stent in this study. However, it is believed that this explains the high incidence of encephalopathy in this series.

Funes FR, Silva RCMA, Arroyo Jr PC, Duca WJ, Silva AAM, Silva RF. Mortalidade e complicações em pacientes com hipertensão portal submetidos a derivação portossistêmica transjugular intra-hepática (TIPS) - 12 anos de experiência. Arq Gastroenterol. 2012;49(2)143-9.

RESUMO - Contexto - Derivação portossistêmica transjugular intra-hepática (TIPS) é opção de tratamento não cirúrgico com baixo índice de morbimortalidade e possibilidade de realização em pacientes com disfunção hepática grave que visa descomprimir o sistema porta tratando ou reduzindo as complicações da hipertensão portal. Objetivo - Traçar o perfil, analisar mortalidade global e precoce, e as complicações apresentadas pelos pacientes cirróticos submetidos a TIPS para tratamento da hemorragia digestiva por hipertensão portal. Métodos - Estudo retrospectivo baseado no banco de dados dos prontuários dos pacientes cirróticos submetidos a TIPS para tratamento da hemorragia digestiva por hipertensão portal que não responderam ao tratamento clínico-endoscópico e atendidos no período de 1998 a 2010 no Serviço de Transplante de Fígado de um hospital universitário. O estudo foi aprovado pelo Comitê de Ética e Pesquisa. Resultados - Amostra foi composta de 72 (84,7\%) pacientes, sendo 57 (79,2\%) do sexo masculino, idade média de 47,4 anos (entre 16 e 85 anos e DP = 13); 21 (29,2\%) pacientes apresentavam como causa da doença hepática o consumo excessivo de álcool; $21(29,2 \%)$ a contaminação por vírus da hepatite, $16(22,2 \%)$ o consumo excessivo de álcool associado a vírus e 14 $(19,4 \%)$ pacientes apresentavam outras causas. Quanto à classificação inicial, 14 (20\%) tinham Child-Pugh A, 33 (47,1\%) Child-Pugh B e 23 (32,9\%) Child-Pugh C. MELD inicial foi obtido em 68 pacientes, sendo $37(54,4 \%)$ com mais de 15 pontos, enquanto $31(45,6 \%)$ tiveram até 15 pontos. Óbito precoce ocorreu em 19 (26,4\%). Mortalidade global ocorreu em 41 (60,3\%). Conclusão - Mortalidade está diretamente relacionada a fatores clínicos dos pacientes, sendo as classificações de Child-Pugh e MELD preditoras de mortalidade, com maior impacto em pacientes com Child-Pugh classe $\mathrm{C}$ e MELD > 15. As complicações encontradas foram semelhantes às descritas na literatura, porém a disfunção por estenose do stent (26,4\%) foi menor que a maioria dos estudos e a incidência de encefalopatia $(58,3 \%)$ superior. Provavelmente, esta alta incidência seja explicada pela baixa incidência de estenose.

DESCRITORES - Derivação portossistêmica transjugular intra-hepática. Hipertensão portal. 


\section{REFERENCES}

1. Angermayr B, Cejna M, Karnel F, Gshwantler M, Koenig F, Pidlich J, Mendel H, Pichler L, Wichlas M, Kreil A, Schmid M, Ferlitsch A, Lipinski E, Brunner H, Lammer J, Ferenci P, Gangl A, Peck-Radosavljevic M. Child-Pugh versus MELD score in predicting survival in patients undergoing transjugular intrahepatic portosystemic shunt. Gut. 2003;52:879-85.

2. Bosch J, Berzigotti A, Garcia-Pagan JC, Abraldes JG. The management of portal hypertension: rational basis, available treatments and future options. J Hepatol. 2008;48(Suppl 1):s68-s92.

3. Boyer TD, Haskal ZJ; American Association for the Study if Liver Diseases. The role of transjugular intrahepatic portosystemic shunt (TIPS) in the management of portal hypertension: update 2009. Hepatology. 2010;51:306.

4. Carreiro G, Moreira AL, Murad FF, Azevedo F, Coelho HS. [TIPS - Transjugular intrahepatic portosystemic shunts. A review]. Arq Gastroenterol. 2001;38:69-80.

5. Chalasani N, Clarck WS, Martin LG, Kamean J, Khan MA, Patel NH, Boyer TD Determinants of mortality in patients with advanced cirrhosis after transjugular intrahepatic portosystemic shunting. Gastroenterology. 2000;118:138-44.

6. da Silva RF, Arroyo PC Jr, Duca WJ, Silva AA, Reis LF, Miquelin DG, Sgnolf A, Cabral CM, Ayres DC, de Lima AP, da Silva RC. Migration of transjugular intrahepatic portosystemic shunt to the right atrium: complications in the intraoperative period of liver transplantation. Transplant Proc. 2008;40:3778-80.

7. Dib N, Oberti F, Calès P. Current management of the complications of portal hypertension: variceal bleeding and ascites. CMAJ. 2006;174:1433-43.

8. Encarnacion CE, Palmaz JC, Rivera FJ, Alvarez OA, Chintapalli KN, Lutz JD, Reuter SR. Transjugular intrahepatic portosystemic shunt placement for variceal bleeding: predictors of mortality. J Vasc Interv Radiol. 1995;6:687-94.

9. Ferguson JW, Hayes PC. Transjugular intrahepatic portosystemic shunt in the prevention of rebleeding in oesophageal varices. Eur J Gastroenterol Hepatol. 2006; 18:1167-71.

10. Ferral H, Gamboa P, Postoak DW, Albernaz VS, Young CR, Speeg KV, McMahan CA. Survival after elective transjugular intrahepatic portosystemic shunt creation: predictor with model for end-stage liver disease score. Radiology. 2004;231:231-6.

11. Garcia-Tsao G, Sanyal AJ, Grace ND, Carey W, Practice Guidelines Committee of American Association for the Study of Liver Diseases; Practice Parameters Committee of the American College of Gastroenterology. Prevention and management of gastroesophageal varices and variceal hemorrhage in cirrhosis. Hepatology. 2007;46:922-38.

12. Gow PJ, Chapman RW. Modern management of oesophageal varices. Postgrad Med J. 2001;77:75-81.

13. Iida VH, Silva TJA, Silva ASF, Silva LFF, Alves VAF. Cirrose hepática: aspectos morfológicos relacionados às suas possíveis complicações. Um estudo centrado em necropsias. J Bras Patol Med Lab. 2005;41:29-36.

14. Jabbour N, Zajko AB, Orons PD, Irish W, Bartoli F, Marsh WJ, Dodd GD 3rd, Andreghitt L, Colangelo J, Rakela J, Fung JJ. Transjugular intrahepatic portosystemic shunt in patients with end-stage liver disease: results in 85 patients. Liver Transplantation Surg. 1996;2:139-47.

15. Kalva SP, Salazar GM, Walker GM. Transjugular intrahepatic portosystemic shunt for acute variceal hemorrhage. Tech Vasc Interv Radiol. 2009;12:92-101.
16. Kemp W, Roberts S. Minimally invasive prediction of esophageal varices and portal hypertension. J Gastroenterol Hepatol. 2009;24:1534 40.

17. Kisilevsky NH. TIPS para o controle das complicações da hipertensão portal: eficácia, fatores prognósticos associados e variações técnicas. Radiol Bras. 2006;39:385-95.

18. Kumar A, Jha SK, Sharma P, Dubey S, Tyagi P, Sharma BC, Sarin SK. Addition of propranolol and isosorbide mononitrate to endoscopic variceal ligation does not reduce variceal rebleeding incidence. Gastroenterolgy. 2009;137:891-901.

19. Lasch HM, Fried MW, Zacks SL, Odell P, Johnson MW, Gerber DA, Sandhu FS, Fair JH, Shrestha R. Use of transjugular intrahepatic portosystemic shunt as a bridge to liver transplantation in a patient with severe hepatopulmonary syndrome. Liver Transpl. 2001;7:147-49.

20. Montgomery A, Ferral H, Vasan R, Postoak DW. MELD score as a predictor of early death in patients undergoing elective transjugular intrahepatic portosystemic shunt (TIPS) procedures. Cardiovasc Intervent Radiol. 2005;28:307-12.

21. Nagula S, Jain D, Groszmann RJ, Garcia-Tsao G. Histological-hemodynamic correlation in cirrhosis-a histological classification of the severity of cirrhosis. J Hepatol. 2006;44:111-7.

22. Owen AR, Stanley AJ, Vijayananthan A, Moss JG. The transjugular intrahepatic portosystemic shunt (TIPS). Clin Radiol. 2009;64:664-74.

23. Rosado B, Kamath PS. Transjugular intrahepatic portosystemic shunt: an update. Liver Transpl. 2003;9:207-17.

24. Russo MW, Jacques PF, Mauro M, Odell P, Brown RS Jr. Predictors of mortality and stenosis after transjugular intrahepatic portosystemic shunt. Liver Transpl. 2002;8:271-7.

25. Sanyal AJ, Chopra S, Travis AC. Complications of transjugular intrahepatic portosystemic shunts [Internet] 2010. [cited 2010 Dec 28]. Available from: http:// www.uptodate.com/contents/complications-of-transjugular-intrahepatic-portosystemic-shunts.

26. Silva RF, Arroyo PC Jr, Duca WJ, Silva AA, Reis LF, Cabral CM, Sgnolf A, Domingues RB, Barao GT, Coelho DJ, Deberaldini M, Felício HC, Silva RC. Complications following transjugular intrahepatic portosystemic shunt: a retrospective analysis. Transplant Proc. 2004;36:926-8.

27. Tzeng WS, Wu RH, Lin CY, Chen JJ, Shen MJ, Koay LB, Lee C. Prediction of mortality after emergent transjugular intrahepatic portosystemic shunt placement: use of APACHE II, Child-Pugh and MELD scores in Asian patients with refractory variceal hemorrhage. Korean J Radiol. 2009;10:481-9.

28. Yoon CJ, Chung JW, Park JH. Transjugular intrahepatic portosystemic shunt for acute variceal bleeding in patients with viral liver cirrhosis: predictors of early mortality. AJR Am J Roentgenol. 2005;185:885-9.

29. Zheng M, Chen Y, Bai J, Zeng Q, You J, Jin R, Zhou X, Shen H, Zheng Y, Du Z Transjugular intrahepatic portosystemic shunt versus endoscopic therapy in the secondary prophylaxis of variceal rebleeding in cirrhotics patients: meta-analysis update. J Clin Gastroenterol. 2008;42:507-16.

30. Zhuang ZW, Teng GJ, Jeffery RF, Gemery JM, Janne d'Othee BJ, Bettmann MA. Long-term results and quality of life in patients treated with transjugular intrahepatic portosystemic shunts. AJR Am J Roentgenol. 2002;179:1597-603.

Received 10/9/2009.

Accepted 30/11/2011 